\title{
GAINS FROM \\ INTERNATIONAL DIVERSIFICATION AND DOMESTIC PORTFOLIO IN EMERGING STOCKS MARKETS: PHILIPPINE AND INDONESIAN PERSPECTIVES
}

\section{Eduardus Tandelilin}

The study was organized into two major concerns: first, identifying the gains from international diversification in emerging stock markets from the Philippine and the Indonesian perspectives and determining which perspective yields the greater gains; and second, determining how many securities must be included to obtain an optimal investment portfolio from the Philippine and Indonesia perspectives.

The empirical results indicate that there are gains from international diversification, both from the Philippine and Indonesian perspectives, in two to eight emerging stock markets. Generally the gains are greater from the Indonesian perspective than the Philippine perspective in all country combinations.

Further, this study found that the number of stocks needed to form an optimum domestic investment portfolio was bigger for the Indonesian investor's perspective (at 15 stocks) than for the Filipino investor (14).

Keywords: characteristics; multinational; performance; U.S. 


\section{Introduction}

\section{Background of the Study}

The benefits from portfolio diversification have been of increasing interest to both investment professionals and academicians. Since the fortunes of different nations do not always move together, investors can diversify their portfolio by holding assets in several countries (French and Poterba 1991). According to Michaud, Bergstrom, and Frashure (1996), international equity portfolio diversification is now well accepted by investors around the world. Foreign diversification has been accepted as a means of improving portfolio efficiency through risk reduction (Solnik 1995;Ziobrowski and Ziobrowski 1995; Odier and Bruno 1995; Eun and Resnik 1994; Madura and Soenen 1992; Haavisto and Hannson 1992; Divecha et. al. 1992; Speidell and Sappenfield 1992; Francis 1991; Levy and Lerman 1988; Levy and Sarnat 1970; among others).

As a result of current aggressive financial market globalization, investors shifted their investment strategies to emerging stock markets away from the more developed countries (Errunza 1994). The Asian Pacific stock markets have been cited as alternative financial interests for international diversification strategies because of their significant developments. According to Pudjiastuti and Husnan (1994), investing in Asian Pacific stock markets is a very effective way of reduc- ing risk, from the U.S. investors' point of view, mainly because the correlation between foreign exchange (i.e. the U.S. dollar) changes and market index changes in some markets is negative. This implies that international diversification of portfolios is instrumental in reducing risk. Moreover, the correlation between market returns in those markets, denominated in U.S. dollars, is very low or even negative.

Recently, however, the issue of emerging stock markets has become more heated. According to the International Finance Corporation (IFC), all stock markets in developing countries are considered as emerging stock markets, ${ }^{1}$ where most of the low and the middle income economies are classified as developing economies or countries.

So far, developed countries have been the focus of studies on international diversification. Thus, empirical studies were mainly on developed capital markets such as the United States. The current study, which focuses on developing countries like the Philippines and Indonesia and touches other emerging markets such as Thailand, Malaysia, Taiwan, South Korea, Pakistan, and India, may be able to contribute to the limited literature on international diversification among developing countries.

Furthermore, several writers have also studied the relation between the riskiness of a portfolio assembled in a home country and the number of securities included. Solnik (1995) showed that risk can be

\footnotetext{
${ }^{1}$ Emerging markets can be defined in different ways. The "emerging market" implies that a market has begun a process of change, growing in size and sophistication, in contrast to markets that are small and give little appearance of change. The term can also refer to any developing economy, with the implication that all have the potential for development. International Finance Corporation (IFC) follows this latter definition. Just as most of the low-and the middle-income economies are considered to be developing, regardless of their particular stage of development, all stock markets in developing countries are considered to be emerging. IFC follows the criteria of the World Bank in classifying economies as low-income, middle-income and high-income (Emerging Stock Markets Factbook 1996, International Finance Corporation, p. 2).
} 
Tandelilin $—$ GainsfromInternationalDiversificationandDomesticPortfolioin...

substantially reduced through diversification in domestic common stocks. This study provides an analysis of the optimal number of stocks needed to achieve a more effective and reasonable diversification at low cost. A risk-averse investor seeking to improve investment performance will learn the important distinction between diversifiable risk and nondiversifiable risk. Newbould and Poon (cited by Colley 1996) recommended that a portfolio of between eight and twenty stocks is the minimum necessary to eliminate diversifiable risk. This paper explores the extent of the benefits of diversification of stock securities in emerging stock markets from the Philippine and Indonesian perspectives.

\section{Objectives of the Study}

Numerous studies have discussed the benefits of international diversification particularly among the developed stock markets (e.g., Solnik 1995; Ziobrowski and Ziobrowski 1995; Odier and Bruno 1995; Eun and Resnik 1994; Madura and Soenen 1992; Haavisto and Hannson 1992; Divecha, et. al. 1992; Speidell and Sappenfield 1992; among others). However, studies focusing on emerging stock markets, specifically the Philippine Stock Market and the Indonesian Stock Markets are limited. A study on the emerging stock markets like the Philippine and Indonesian experiences will be able to provide additional evidence in this area of concern.

The central purpose of this study is to focus on the emerging stock markets, particularly the Philippine Stock Exchange (PSE) and the Jakarta Stock Exchange (JSX) in terms of diversification. Specifically, this paper aims to answer the following questions:
1. Are there gains from international diversification in emerging stock markets (Thailand, Malaysia, Taiwan, South Korea, Pakistan and India) from the Philippine and the Indonesian perspectives? Where are the gains greater?

2. How many securities must be included to obtain an optimal investment portfolio from the Philippine and Indonesian perspectives?

\section{Review of Related Literature}

Although several empirical studies have shown the benefits of international diversification of portfolios, no study has been done on the Philippine and Indonesian perspectives. The closest related literature was an empirical survey of Indonesian equities (1985-1992) by Richard Roll in 1995. Using a new database of equities listed in the Jakarta Exchange, historical returns were documented for the 19851992 period. He found that Jakarta stocks had high volatility relative to other countries and Jakarta's value stocks (those with low market/book value ratios) performed much better than growth stocks.

In terms of international diversification, Greenwood (1993, as cited by Lamberte 1994) made some estimations with regard to investment in stocks. It was estimated that with a 60 percent U.S. and 40 percent Far East ex-Japan portfolio, returns can be increased by 1.5 percent per annum for the same level of risk, or alternatively, with an 80 percent U.S. and 20 percent Far East ex-Japan portfolio, returns can be raised by 0.75 percent per annum while risk can be reduced.

Similarly, the gains from international diversification of investment portfolios from the Japanese as well as the U.S. perspectives were analyzed by Eun and 
Resnick (1994). Their major findings were: (1) the potential gains from international, as opposed to purely domestic, diversification, are much greater for U.S. investors than for Japanese investors; for U.S. investors, the gains accrue not so much in terms of lower risk as in terms of higher return, the opposite holds for Japanese investors; (2) using various ex-ante international investment strategies designed to control parameter uncertainty, U.S. investors can realize substantial gains from international diversification; and (3) hedging exchange risk generally allows U.S. investors, but not Japanese, to benefit more from international diversification.

The benefits of international diversification were further examined over time by Madura and Soenen (1992). They compared different investors' perspectives and suggested that Japanese investors were likely to benefit from international diversification. On an inter-temporal basis, the risk characteristics improved the most for the Swiss perspective and worsened for the U.S. perspective. These research results prove that gains from international diversification continue to exist regardless of the country perspective. Thus, there is no conclusive evidence that the gains from international diversification decrease over time.

On the other hand, Haavisto and Hansson (1992) analyzed potential gains from international diversification for different Nordic investors (Danish, Finnish, Norwegian and Swedish) if they invested in all the Nordic equity markets. Three interesting empirical results were obtained from the study. First, it was shown that for an investor with a long investment horizon, the exchange rate risk was negligible. Second, the derivation of the ex post effective frontier suggests that there would have been ample scope for actually reducing risk by Nordic diversification. Third, the ex post optimal portfolios were extremely concentrated and included in general only Finnish and Swedish assets, which is an indication of segmented markets. The study concluded that for the period under consideration, a long-term investor would have done very well by keeping a non-hedged and diversified Nordic portfolio.

In international diversification, it is important to consider domestic conditions. Domestic securities tend to move up and down together because they are similarly affected by domestic conditions, such as money supply announcements, movements in interest rates, budget deficit and national growth (Solnik 1996). These create the strong positive correlation among all domestic stocks traded in the same market. Foreign capital stock markets, because they are not affected by these, provide a way for domestic residents to diversify their portfolios internationally (Solnik 1996, Ziobrowski and Ziobrowski 1995; Elton and Gruber 1994; Bart 1992; Divecha et al. 1992; and Speidel and Sappenfield 1992).

Recently, Solnik (1995) showed that substantial advantages in risk reduction can be attained through portfolio diversification in foreign securities as well as in domestic common stocks. The total risk of a portfolio will depend not only on the number of securities included in the portfolio, but also on the riskiness of each individual security and the degree to which these risks are independent.

In another perspective, Cosset and Suret (1995) studied the benefits of portfolio investment in the stock markets of politically risky countries by evaluating the effects of political risk constraints on the performance of a portfolio of international stocks. They used ex post and exante portfolio selection strategies which 
were developed to assess the gains from international diversification. In light of their empirical findings, they suggested that diversification among politically risky countries improves the risk-return characteristics of optimal portfolios.

In 1992, Brainard and Tobin studied internationalization of portfolios and observed that optimal portfolio diversification lowers the risk premia. However, they noted that the risk-free rate was raised by more than the reduction in the risk of premium, hence, the rate of return on foreign equity also rises. Bart (1992) had similar observations. He indicated that diversification helps investors minimize the risks that arise from unforeseen developments in the world economy, the national economy, competition and corporate management. He concluded that to achieve maximum risk-reduction, it is necessary to create a mix of securities whose returns do not move up and down together in response to the same developments. Risk is further reduced by introducing stocks from different countries under economic conditions that are different from those in the investor's home country.

Moreover, several writers have also studied the relations between the riskiness of a portfolio assembled in a home country and the number of securities included. Solnik (1995) showed that risk can be substantially reduced through diversification in domestic common stocks. This study provides an analysis of the optimal number of stocks needed to achieve a more effective and reasonable diversification at low cost. A risk-averse investor seeking to improve investment performance will learn the important distinction between diversifiable risk and nondiversifiable risk. Newbould and Poon (cited by Colley 1996) recommended that a portfolio of between eight and twenty stocks is the minimum necessary to eliminate diversifiable risk. This paper explores the extent of the benefits of diversification of stock securities in emerging stock markets from the Philippine and Indonesian perspectives.

\section{Methodology}

The focus of the study is mainly on portfolio diversification in Asian emerging stock markets, with emphasis on the Philippine and Indonesian stock markets. A conceptual framework is developed to show the logical flow of analysis and the significant variables in the study. The conceptual framework generally shows that gains from international diversification depend on returns, standard deviation and correlation of stock return index for each country. On the other hand, gains from domestic diversification generally depend on the returns, standard deviation and correlation of stocks. These were basically analyzed from the Philippine and Indonesian perspectives. In this framework, potential gains from international diversification by investors from both countries are compared.

The Philippine and Indonesian stock markets are used to test the validity of this framework. Figure 1 represents the conceptualized framework.

The conceptual framework involves two (2) major areas. First, it deals with international diversification by analyzing eight (8) emerging stock markets. These are the Philippines, Indonesia, India, Malaysia, Pakistan, South Korea, Taiwan, and Thailand. The stock price indices of each country were considered to be able to determine the potential gains from international diversification, both from the Philippine and Indonesian perspectives. The result will be the basis for determining 
Figure 1. Conceptual Framework

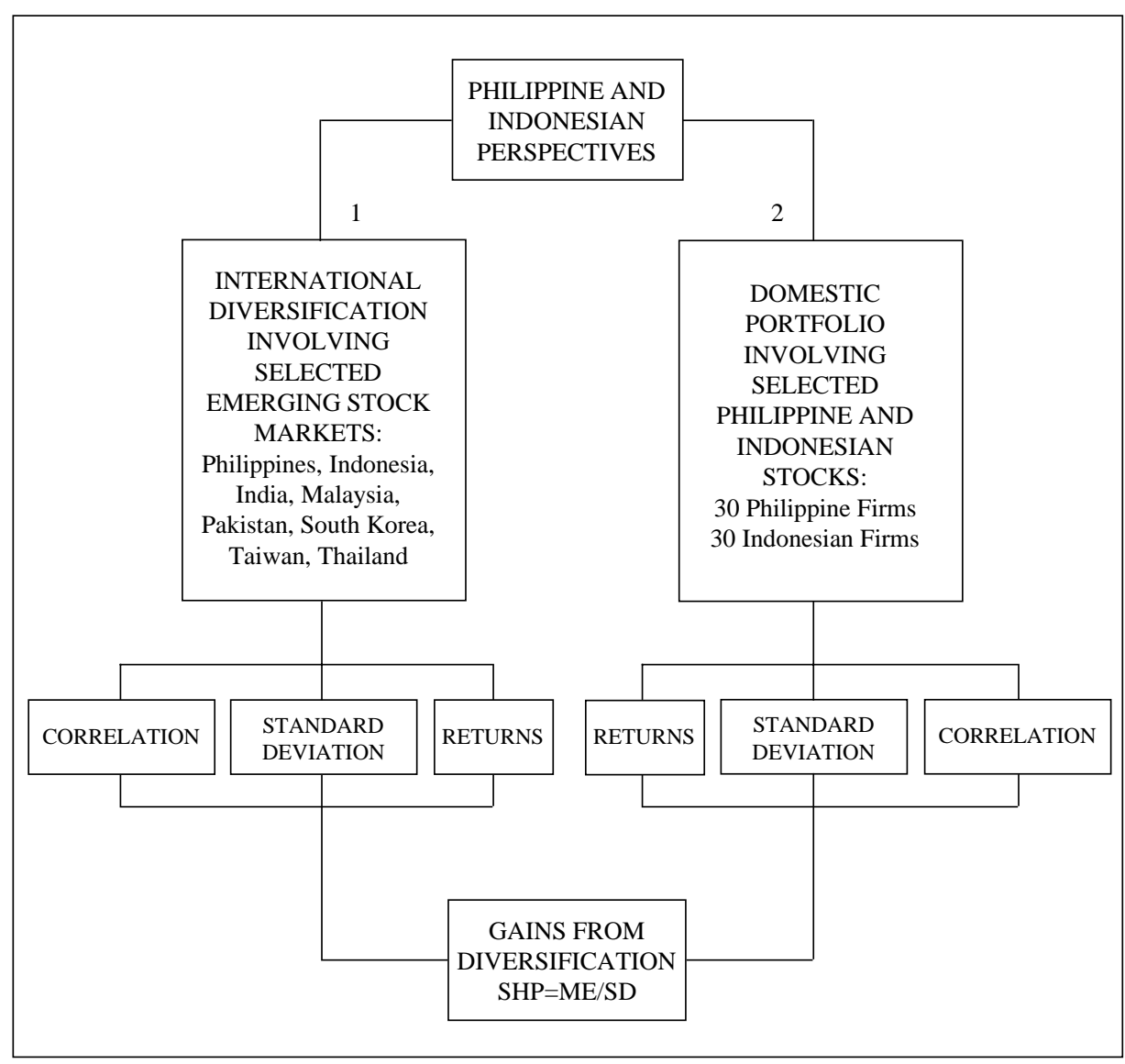

which perspective yields the greater gains. Second, the framework presents an analysis of domestic portfolio by determining the gains based on relative returns and standard deviations (or termed as Sharpe ratio) for randomly selected portfolios from the Philippines and Indonesia. Comparison was made between the Philippine and Indonesian portfolios in terms of the number of stocks needed for an optimal investment portfolio.

The sample, aside from the main focus of the study which are the Philippines and Indonesia, include other emerging stock markets such as Thailand, Malaysia,
Taiwan, South Korea, Pakistan, and India. The monthly International Finance Corporation Global (IFCG) Price Indices that were used for all the samples covered the years 1990 to 1995 . The price indices were correspondingly adjusted in terms of the U.S. dollar.

The sample firms included 30 firms from the Philippine Stock Exchange (PSE) and 30 firms from Jakarta Stock Exchange (JSX), or a total of 60 firms. These firms were selected as follows: sixty firms were chosen from the list of firms registered with the Philippine Stock Exchange; the same was done for Indonesia; stock re- 
Tandelilin —GainsfromInternationalDiversificationandDomesticPortfolioin...

ports of the chosen firms were then examined; only firms which had transactions at least once a month were retained; fifteen (15) Philippine firms and ten (10) Indonesian firms were thus excluded; thirty firms from each of the countries were then randomly selected from the remaining 45 Philippine firms and 50 Indonesian firms. For the Philippines, the market capitaliza- tion of these 30 firms is 25 percent of the total while for Indonesia, the market capitalization for these 30 firms is 29 percent of the total. This is based on the year 1995 . All the stock prices were adjusted in terms of stock dividends, stock splits and rightissue for both the Philippine and Indonesian stocks.

Table 1. List of Samples

\begin{tabular}{|c|c|}
\hline Philippine Stocks & Indonesian Stocks \\
\hline 1. Ayala Corporation & 1. P.T. Astra International \\
\hline 2. San Miguel Corporation & 2. P.T. Indocement Tunggal Prakarsa \\
\hline A. Soriano Corporation & 3. P.T. Gudang Garam \\
\hline 4. Metro Pacific Corporation & 4. P.T. United Tractors \\
\hline 5. Philippine Long Distance Telephone Co. & 5. P.T. Bakrie Sumatra Plantations \\
\hline 6. EEI Corporation & 6. P.T. Hero Supermarket \\
\hline 7. Republic Glass Holding Corporation & 7. P.T. Roda Vivatex \\
\hline 8. Bacnotan Consolidated Industries, Inc. & 8. P.T. Central Proteinaprima \\
\hline 9. First Philippine Holdings Corporation & 9. P.T. Dharmala Agrifood \\
\hline 10. Republic Cement Corporation & 10. P.T. Internasional Nickel Indonesia \\
\hline 11. Sanitary Wares Manufacturing Co. & 11. P.T. Petrosea \\
\hline 12. Ayala Land Inc. & 12. P.T. Apac Centertex Corporation \\
\hline 13. SM Development Corporation & 13. P.T. Inti Indorayon Utama \\
\hline 14. Philex Mining Corporation & 14. P.T. Trias Sentosa \\
\hline 15. RFM Corporation & 15. P.T. Hanjaya Mandala Sampoerna \\
\hline 16. Benguet Corporation & 16. P.T. Supreme Cable Manufacturing Co. \\
\hline 17. Guoco Holding (PHILS.), Inc. & 17. P.T. Tigaraksa Satria \\
\hline 18. Robinson's Land Corporation & 18. P.T. Gadjah Tunggal \\
\hline 19. Philippine Realty Holding & 19. P.T. Unilever Indonesia \\
\hline 20. Sime Darby Pilipinas, Inc. & 20. P.T. Rig Tenders Indonesia \\
\hline 21. Dizon Copper - Silver Mines, Inc. & 21. P.T. NVPD Soedarpo Corporation Corporation \\
\hline 22. Jardine Davies, Inc. & 22. P.T. Duta Anggada Realty \\
\hline 23. Lepanto Consolidated Mining Co. & 23. P.T. Astra Graphia \\
\hline 24. Interphil Laboratories, Inc. & 24. P.T. Great River International \\
\hline 25. Kuok Philippine Properties, Inc. & 25. P.T. Unggul Indah Corporation \\
\hline 26. Manila Mining Corporation & 26. P.T. Pakuwon Jati \\
\hline 27. House of Investment, Inc. & 27. P.T. Semen Cibinong \\
\hline 28. Trans-Asia and Mineral Dev't. Co. & 28. P.T. Summarecon Agung \\
\hline 29. Seafront Resources Corporation & 29. P.T. Tembaga Mulia Semanan \\
\hline 30. Dharmala Philippines, Inc. & 30. P.T. Multipolar Indonesia \\
\hline
\end{tabular}


Gadjah MadaInternationalJournal ofBusiness, September1999, Vol.1,No. 2

\section{Methodological Procedures}

There are major assumptions that were made in the study. These assumptions apply to international and domestic portfolio components.

1. There are no transaction costs. There is no cost (friction) of buying or selling any asset.

2. There are no taxes.

3. Unlimited short sales are allowed.

4. All assets are risky.

5. Investors are concerned with the mean and variance of returns (or prices over a single period)

\section{A. For International Diversification}

In order to examine correlation between returns of Philippine and Indonesian stocks and returns of stocks of emerging stock markets, the IFCG Total Return Indices were used. The returns have been calculated in dollars and, therefore, the indices were adjusted to reflect any changes in exchange rates during the period. As a result, the rates of returns that were used in this study are the relevant rates for investors in pesos or rupiah. The monthly rate of return for each country is defined as the percentage change in dollar value of its index of common stocks. The following formula was employed to calculate monthly rate of returns:

$$
\mathrm{R}_{\mathrm{it}}=\left(\mathrm{P}_{\mathrm{i}, \mathrm{t}}-\mathrm{P}_{\mathrm{i}, \mathrm{t}-\mathrm{1}}\right) / \mathrm{P}_{\mathrm{i}, \mathrm{t}-1}
$$

where $P_{i t}$ and $P_{i, t-1}$ represent the dollar value of the current month $t$ and previous $t-1$ monthly country's stock index. $R_{i t}$ represents the rate of return in month $t-1$.

The following formula was employed to examine correlation between returns of Philippine and Indonesian stocks and returns of stocks of emerging markets:

$$
r\left(\mathrm{r}_{\mathrm{it}}, \mathrm{r}_{\mathrm{jt}}\right)=\frac{\operatorname{Cov}\left(\mathrm{r}_{\mathrm{it}}, \mathrm{r}_{\mathrm{jt}}\right)}{\mathrm{s}_{\mathrm{it}}, \mathrm{s}_{\mathrm{jt}}}
$$

where $\operatorname{Cov}\left(r_{i t}, r_{j t}\right)$ represents the covariance between stock returns of country $i$ in month $t$, and stock returns of country $j$ in month $t$; and $s_{i t}, s_{j t}$ represent the standard deviation of stock returns of country $i$ in month $t$ and stock returns of country $j$ in month $t$, respectively.

The potential gains from international diversification were determined by solving for the optimal international (tangency) portfolios to the domestic (Philippines and Indonesia) portfolios, then comparing their risk-return characteristics to that of the domestic portfolios. In solving for the optimal international portfolios, monthly return data for national stock market indices from the period January 1990 through December 1995 were used. Formally, the tangency portfolio will be identified by solving the following maximization problem (Eun and Resnick 1994):

$$
\begin{aligned}
& \operatorname{Maxq}_{\left(X_{i}\right)} \frac{E\left(R_{p}\right)-R_{f}}{S_{p}}
\end{aligned}
$$

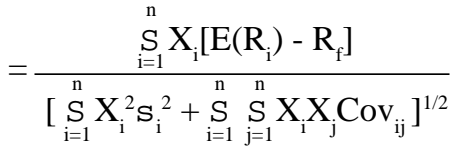

$$
\begin{aligned}
& \text { subject to }=\mathrm{S}_{\mathrm{i}=1}^{\mathrm{N}} \mathrm{X}_{i}=1.0
\end{aligned}
$$

where:

$\mathrm{X}_{\mathrm{i}}=$ the fraction of wealth invested $i^{\text {th }}$ security

$\mathrm{E}\left(\mathrm{R}_{\mathrm{i}}\right)=$ the expected return on the $i^{\text {th }}$ security

$E\left(R_{p}\right)=$ the expected return on the portfolio 
Tandelilin—GainsfromInternationalDiversificationandDomesticPortfolioin...

$\mathrm{R}_{\mathrm{f}} \quad=$ the risk-free interest rate

$r_{\mathrm{ij}}=$ the covariance of returns between the $i^{\text {th }}$ and $j^{\text {th }}$ securities

$\mathrm{S}_{\mathrm{p}} \quad=$ the standard deviation of returns of the portfolio.

In order to compare the gains of diversification in emerging stock markets for Philippine and Indonesian investors, Sharpe Ratio was used. The following is the formula of Sharpe Ratio:

$$
\mathrm{SHP}=\left[\mathrm{E}\left(\mathrm{R}_{\mathrm{p}}\right)-\mathrm{R}_{\mathrm{f}}\right] / \mathrm{s}_{\mathrm{p}}
$$

In summary, from the data from the IFC Global Index of the eight (8) emerging countries, the mean, standard deviation and correlation were computed. The next step involved computing all possible combinations (a total of 256 combinations) of portfolio diversification with two to eight other Asian emerging stock markets from the Philippine and Indonesian perspectives. Thereafter, the Sharpe Ratio, the mean and optimum gains were derived. For mean gain, the average of all possible combinations were computed. On the other hand, the optimum gain was based on the highest Sharpe Ratio obtained from all the possible combinations. The optimal international portfolio is that which produces the largest gain. The last step involved comparing the mean and optimum gains from the Philippine and Indonesian perspectives.

\section{B. For Domestic Portfolio}

The data used in estimating the relationship between diversification and the level of variation of portfolio returns was computed on the 60 stocks listed in the PSE and JSX. Observation on each stock was taken at monthly intervals for the period January 1991-December 1995 . The statistics employed in the calculation of ex-post returns and the dispersion of these returns was the geometric mean and the standard deviation of the logarithms of the value relatives.

To demonstrate the effect of changing the number of stocks held in a portfolio, random sample portfolios were constructed holding from two to twenty-five securities (stocks). In order to reduce the dependence on single samples, the exercise was repeated thirty (30) times with different random selections. This was done to find the optimum portfolio for stock returns and standard deviations to be able to compute for the Sharpe ratio.

The ex-post monthly return for period $t$ was calculated for each stock from the following formula, where $R_{(k, t)}$ is the value relative (computed return) for security $k$ in period $t, P_{k, t}$ is the price of stock $k$ at the beginning of period $t, P_{(k, t+l)}$ is the price of stock $k$ at the end of period $t$, and $d_{(k, i)}$ is the dividend paid on stock $k$ during period $t$ :

$$
\begin{gathered}
\mathrm{R}_{\mathrm{k}}=\left(\frac{\mathrm{P}_{(\mathrm{k}, \mathrm{i}+1)}+\mathrm{d}_{(\mathrm{k}, \mathrm{t})}}{\mathrm{P}_{(\mathrm{k}, \mathrm{t})}}\right) \\
\text { for } t=1 \text { to } 60 \text {, and } k=1 \text { to } 30
\end{gathered}
$$

The average return over the 60 periods for each stock is given by the following, where $\bar{R}_{k}$ is the geometric mean return for stock $k$ :

$$
\begin{gathered}
\overline{\mathrm{R}}_{\mathrm{k}}=\exp \left((1 / \mathrm{n}){\underset{\mathrm{t}}{\mathrm{n}=1}}_{\text {for } n=60, \text { and } k=30} \ln \frac{\mathrm{P}_{(\mathrm{k}, \mathrm{t}+1)}+\mathrm{d}_{(\mathrm{k}, \mathrm{i})}}{\mathrm{P}_{(\mathrm{k}, \mathrm{t})}}\right) \\
\end{gathered}
$$

The standard deviation of the logarithms of the value relatives (the measure of risk) for stock $k$ over the 60 periods was computed as follows: 


\section{Gadjah MadaInternationalJournal ofBusiness, September1999, Vol.1,No. 2}

$$
\begin{gathered}
\mathrm{SD}_{\mathrm{k}}=\sqrt{\frac{\mathrm{S}_{\mathrm{i}=1}^{\mathrm{n}}\left(\mathrm{R}_{\mathrm{k}, \mathrm{t}}+\mathrm{R}_{\mathrm{k}, \mathrm{t}}\right)^{2}}{\mathrm{n}-1}} \\
\text { for } n=60 \text { and } k=30
\end{gathered}
$$

In summary, the optimal number of stocks in the portfolio was determined by the following steps: first, all possible firms from the Philippine and Indonesian stock markets were selected; the trading records were checked to determine whether these non-financial firms traded at least once a month and their financial records from 1991 to 1995 were available; second, thirty from each of the countries were randomly selected; third, the monthly stock prices were adjusted in terms of stock dividends, stock splits and right offering or issue; stock returns were computed; random combinations for each portfolio consisting of 2 to 25 stocks were done, for a total of 1,440 combinations; computation of the optimum portfolio was later done using the Investment Portfolio software (Version 1) by Elton and Gruber (1995); and fourth, the Sharpe Ratio was computed for the 1,440 combinations.; the ANOVA was employed to determine the optimum number of stocks to be included in the portfolio. This was done for both the Philippine and Indonesian stocks.

\section{Discussion and Analysis of Findings}

This section presents a discussion and analysis of the findings. The first part of the section is an exploration of the gains from international diversification in emerging stock markets (Thailand, Malaysia, Taiwan, South Korea, Pakistan, and India) from the Philippine and Indonesian perspectives. In the second part, the rate of the variation of the returns for randomly selected stocks to form domestic portfolios is examined. Alongside this, the discussion will also focus on the tests to determine the number of securities that may be included to obtain an optimal investment portfolio for Philippine and Indonesian investors.

\section{On International Diversification}

Bailey and Stulz (1990), Solnik (1995), Madura and Soenen (1992) extensively discussed the benefits of international diversification. They concluded from their analysis that benefits are substantial in international diversification. Earlier, Errunza (1988) provided further evidence on the benefits of portfolio investments in emerging markets. The data in the current study support the contention of Bailey and Stulz, as well as Errunza's, that there are gains in international diversification. Moreover, the positive percentage gains as reflected in the differences between international diversification and domestic portfolio in terms of Sharpe ratio (SHP) indicate that there are benefits that can be derived from diversifying internationally. The data analysis involved diversifying investment in two to eight countries taken from the Philippine and Indonesian perspectives.

To determine if there are gains in international diversification from the Philippine and Indonesian perspectives, the emerging stock markets were combined in combinations consisting of two to eight markets. Subsequently, the average mean SHPs and percentage gains were computed. Table 2 presents the results of all the possible combinations and their corresponding Mean SHPs and percentage gains. 
Tandelilin—GainsfromInternationalDiversificationandDomesticPorffolioin...

Table 2. Comparison Between Philippine and Indonesian Perspectives in Terms of Percentage Gains of Mean SHP

\begin{tabular}{|l|c|c|c|c|}
\hline \multirow{2}{*}{ Portfolio of: } & \multicolumn{2}{|c|}{ Philippine Perspective } & \multicolumn{2}{c|}{ Indonesian Perspective } \\
\cline { 2 - 5 } & \multicolumn{2}{|c|}{ (Domestic SHP = 0.1176) } & \multicolumn{2}{|c|}{ (Domestic SHP = 0.0769) } \\
\cline { 2 - 5 } & Mean SHP* & Gains (\%)** & Mean SHP* & Gains (\%)** \\
\hline 2 Countries & 0.1463 & 24.38 & 0.1302 & 69.35 \\
3 Countries & 0.1730 & 47.15 & 0.1607 & 109.03 \\
4 Countries & 0.1910 & 62.43 & 0.1877 & 144.11 \\
5 Countries & 0.2061 & 75.22 & 0.2050 & 166.55 \\
6 Countries & 0.2186 & 85.92 & 0.2187 & 184.42 \\
7 Countries & 0.2319 & 97.16 & 0.2307 & 199.97 \\
8 Countries & 0.2405 & 104.51 & 0.2405 & 212.74 \\
\hline
\end{tabular}

* Mean SHP is the average mean for each combination

** Percentage gains is computed by deducting the Mean SHP from the Domestic SHP over Domestic SHP multiply by 100 (e.g. in 8 countries for the Philippine perspective, $(0.2405$ $0.1176) / 0.1176 \times 100=104.51) . R f=0$.

Table 3. Comparison Between Philippine and Indonesian Perspectives in Terms of Percentage Gain of Optimum Combination SHP

\begin{tabular}{|l|c|c|c|c|}
\hline \multirow{2}{*}{ Portfolio of: } & \multicolumn{2}{|c|}{ Philippine Perspective } & \multicolumn{2}{c|}{ Indonesian Perspective } \\
\cline { 2 - 5 } & $\begin{array}{c}\text { (Domestic SHP = 0.1176) } \\
\text { (Domestic SHP = 0.0769) }\end{array}$ & $\begin{array}{c}\text { Optimal } \\
\text { SHP* }\end{array}$ & Gains (\%)** \\
\cline { 2 - 5 } & SHP* & Gains (\%)** & 0.2000 & 160.08 \\
\hline 2 Countries & 0.1932 & 64.27 & 0.2169 & 182.01 \\
3 Countries & 0.2152 & 82.98 & 0.2333 & 203.42 \\
4 Countries & 0.2273 & 93.26 & 0.2375 & 208.84 \\
5 Countries & 0.2326 & 97.75 & 0.2375 & 208.84 \\
6 Countries & 0.2368 & 101.40 & 0.2375 & 208.84 \\
7 Countries & 0.2400 & 104.08 & 0.2405 & 212.74 \\
8 Countries & 0.2405 & 104.51 & \\
\hline
\end{tabular}

* Optimum SHP refers to the highest SHP from all possible combinations for two up to eight countries.

Refer to Appendix B for details.

** Percentage gains is computed by deducting Optimum SHP from Domestic SHP/over Domestic SHP multiply by 100 . 
Table 2 indicates that for both the Philippine and Indonesian perspectives, there are gains from diversifying in the different emerging stock markets. It can be noted that on the basis of Mean SHP, the Philippines appears to be higher than Indonesia in most combinations, except for the 6-country combination. However, taking into account their respective domestic SHPs, the resulting percentage gains indicate that Indonesia seems to be higher than the Philippines.

From all the possible country combinations, the highest Sharpe ratio was chosen. The countries that have the highest SHP constitute the optimum portfolio diversification from two to eight possible country combinations. Table 3 presents the optimum SHPs and the corresponding percentage gains from the Philippine and Indonesian perspectives.

With respect to optimum SHPs, there seem to be a mix of results. From the Indonesian perspective, it is higher, compared to the Philippine perspective, for 2, $3,4,5$ and 6 country combinations. On the other hand, the Philippine perspective is higher in 7 country combinations. However, the Indonesian perspective is higher than the Philippine perspective in all country combinations in terms of percentage gains. The following figure further shows the comparative results in terms of optimum SHPs from the Philippine and Indonesian perspectives.

The results generally indicate that gains from international diversification can be derived from either investing in the countries that have low correlation in their respective stock returns or the countries that have high stock returns. Moreover, the results further imply that for standard deviation to be reduced, countries that have the lowest correlation may be chosen. On the other hand, if gains from international diversification in terms of high returns are the primary consideration, the countries with high returns may be chosen. The gains therefore of international diversification can be derived from investing in countries with high stock returns or those with lower standard deviations. According to Bailey and Stulz (1992), the extent to which the variance can be reduced depends on the variance of the foreign indices, on their correlation with the home country (in this case, the Philippines and Indonesia) and other foreign countries (the emerging stock markets), and on their mean returns.

One aspect of the study that is significant is the relationship between volatility and correlation. Iben and Litterman in their study of 1994 asked whether return correlation in general increase with the level of market volatility. Their findings show mixed results. From a U.S. investor's perspective, there is no systematic positive relationship between the level of volatility and correlation. However, from the perspective of Germany and Japan, there seems to be a positive relationship between levels of volatility and correlation. Additionally, their study found that while volatility has increased markedly for international investors, diversification benefits have remained relatively stable. In the current study, it is interesting to note that while the volatility (standard deviations) of the Philippine stocks is higher than the Indonesian stocks, the correlation are almost the same. This finding supports the U.S. experience.

Furthermore, from the Indonesian perspective, the gain from international diversification is from high returns and low standard deviation in combinations up to four countries. However, for the five- to eight- country combinations, the gain is from high returns and not from low stan- 
Tandelilin—GainsfromInternationalDiversificationandDomesticPorffolioin...

Figure 2. Comparative Results Between The Philippine and Indonesian Stocks in Terms of Mean and Standard Deviations

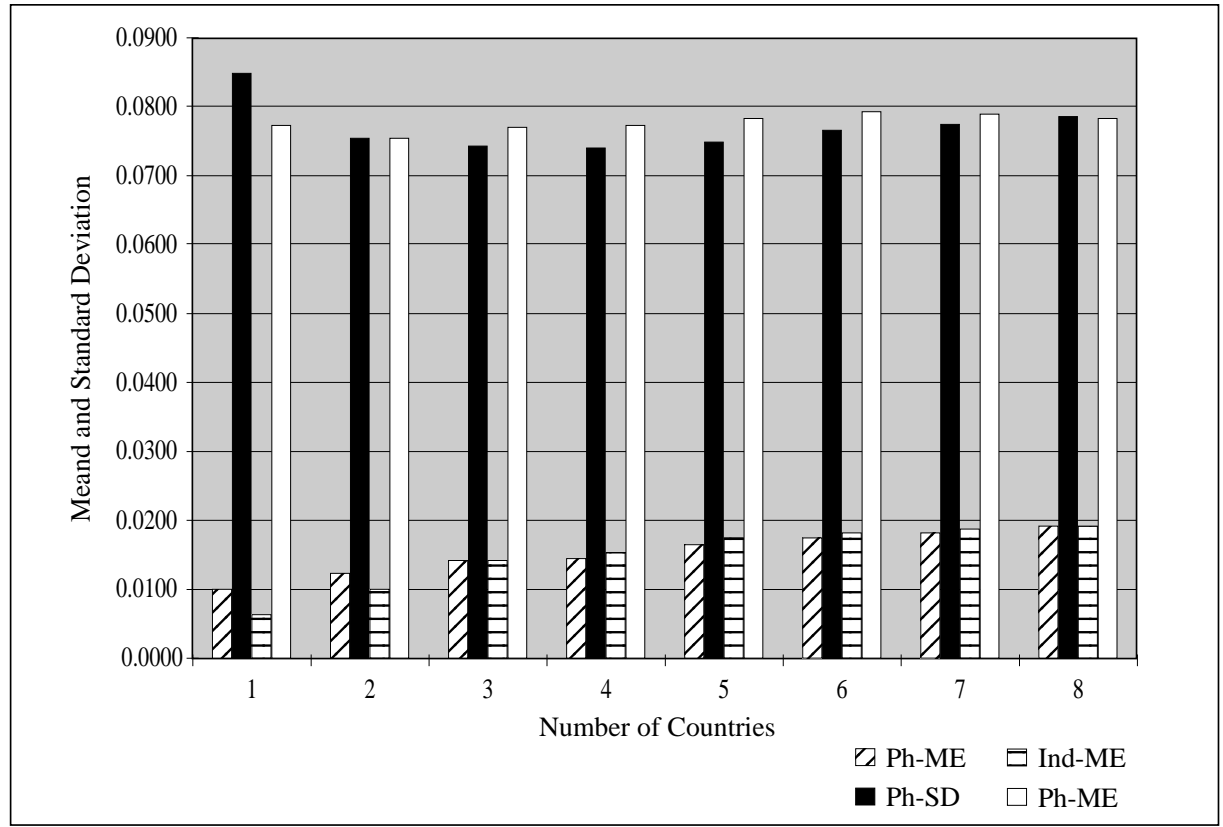

Figure 3. Trends of the Philippine Peso and the Indonesian Rupiah (In Relation to the U.S. Dollar Rate) From 1991-1995

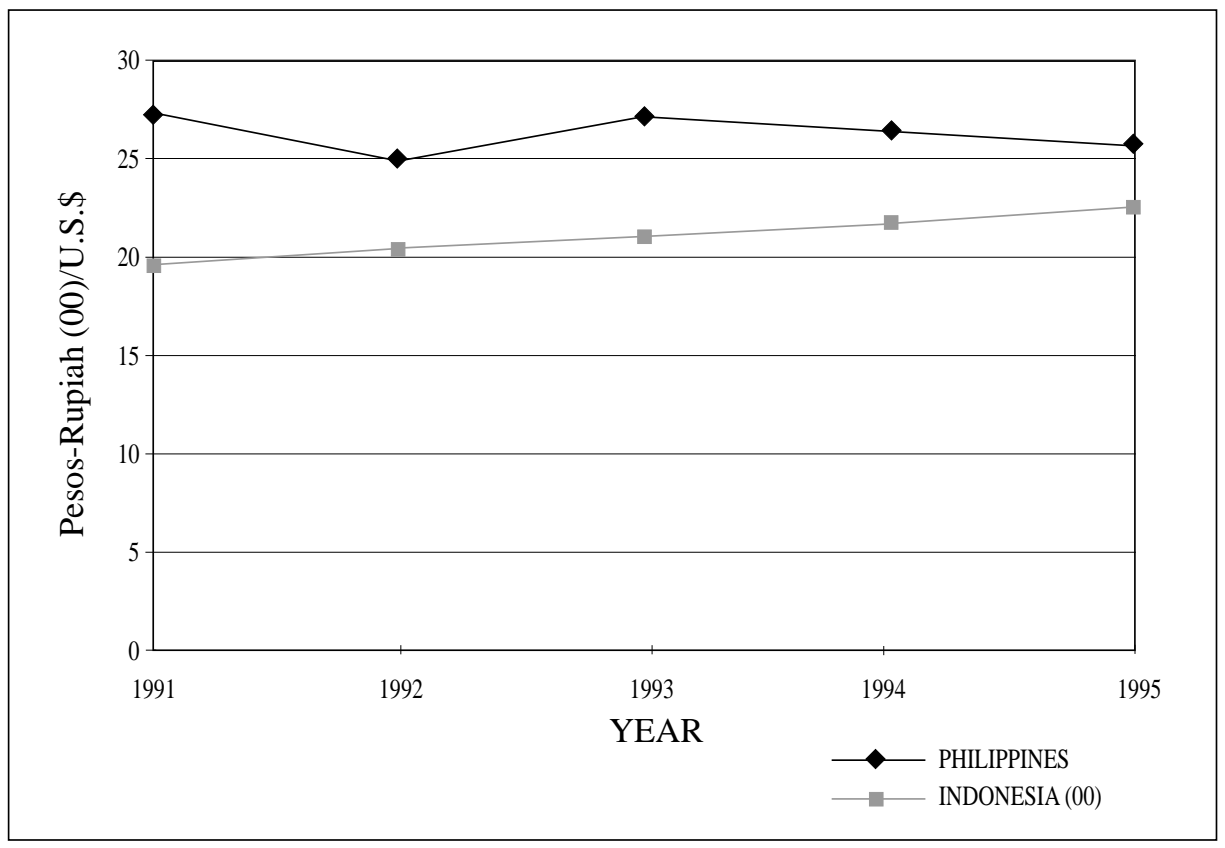


dard deviation. However, both Indonesia and the Philippines gained from international diversification as can be seen in Table 2 and Table 3.

In comparison, however, the gain based on SHP is higher from the Indonesian perspective than from the Philippine perspective. One reason could be that Indonesia has a lower mean return and SHP than the Philippines. It is therefore much easier to achieve greater gains from the Indonesian perspective (Figure 2).

Another reason could be the differences in exchange rate (all the computations are in terms of dollar returns; proper adjustments to the dollar were made). For the selected time period, the Philippine peso remained relatively stable and less depreciated as compared to the Indonesian rupiah which constantly depreciated visa-vis the dollar. Figure 3 shows the trends of the Philippine peso and the Indonesian rupiah in relation to the dollar from 1991 to 1995.

The current study did not include directly the significant impact of foreign exchange risk as a variable in international diversification. However, many studies have indicated that foreign exchange hedging plays an important role in international investment decisions. Filatov and Rappoport (1992), for instance, indicated that if covariance between exchange rate and stock returns are zero or positive it will be optimal to be fully or even over-hedged. It means that currency exposure contributes to diversification if depreciation of the domestic currency tends to be accompanied by lower-than-average foreign and domestic returns, denominated in their local currencies. Eun and Resnick (1994) tried to integrate foreign currency as an important component of foreign investment risk between U.S. and Japanese investors. They found that hedging exchange risk is found to generally increase the benefits from international investment but only for the U.S. investor. The finding was based on the depreciation of the yen vis-avis the dollar. As a whole, while it is true that foreign currency hedging is an important variable in international diversification, Odier and Solnik (1993) implied that, unfortunately, there is no formula for determining whether or not to hedge currency risk or even how much of it to hedge. They added that the difficulty of arriving at an optimal currency-hedging policy in part reflects the lack of an observable, universally efficient portfolio for international stocks and equity.

\section{On Domestic Diversification}

This section focuses on the domestic portfolio and presents the gains from relative returns and standard deviations (variations), or Sharpe Ratio (SHP), for randomly selected portfolios for the Philippines and Indonesia. Included here is a presentation of the results which show the increase of Sharpe ratio (SHP) as a function of the number of stocks included in the portfolio.

In the analysis of the Philippine experience, the gains in terms of Sharpe ratio were registered in portfolios with up to fourteen (14) stocks. This simply means that increase of Sharpe ratio can only be obtained with up to fourteen stocks in the portfolio; beyond fourteen, there is no difference. This is shown by the ANOVA analysis (Figure 4).

Table 4 further shows analysis to support the multiple range tests. It aims to present a validation of the above results.

Therefore, for the Philippines, fourteen (14) is the optimal number of stocks to derive gains in terms Sharpe ratio(SHP). On the other hand, the Indonesian experience shows a higher number at 15 . 
Tandelilin—GainsfromInternationalDiversificationandDomesticPortfolioin...

Figure 4. Results of ANOVA for Optimum Number of Stocks in the Portfolio for Philippine Stocks

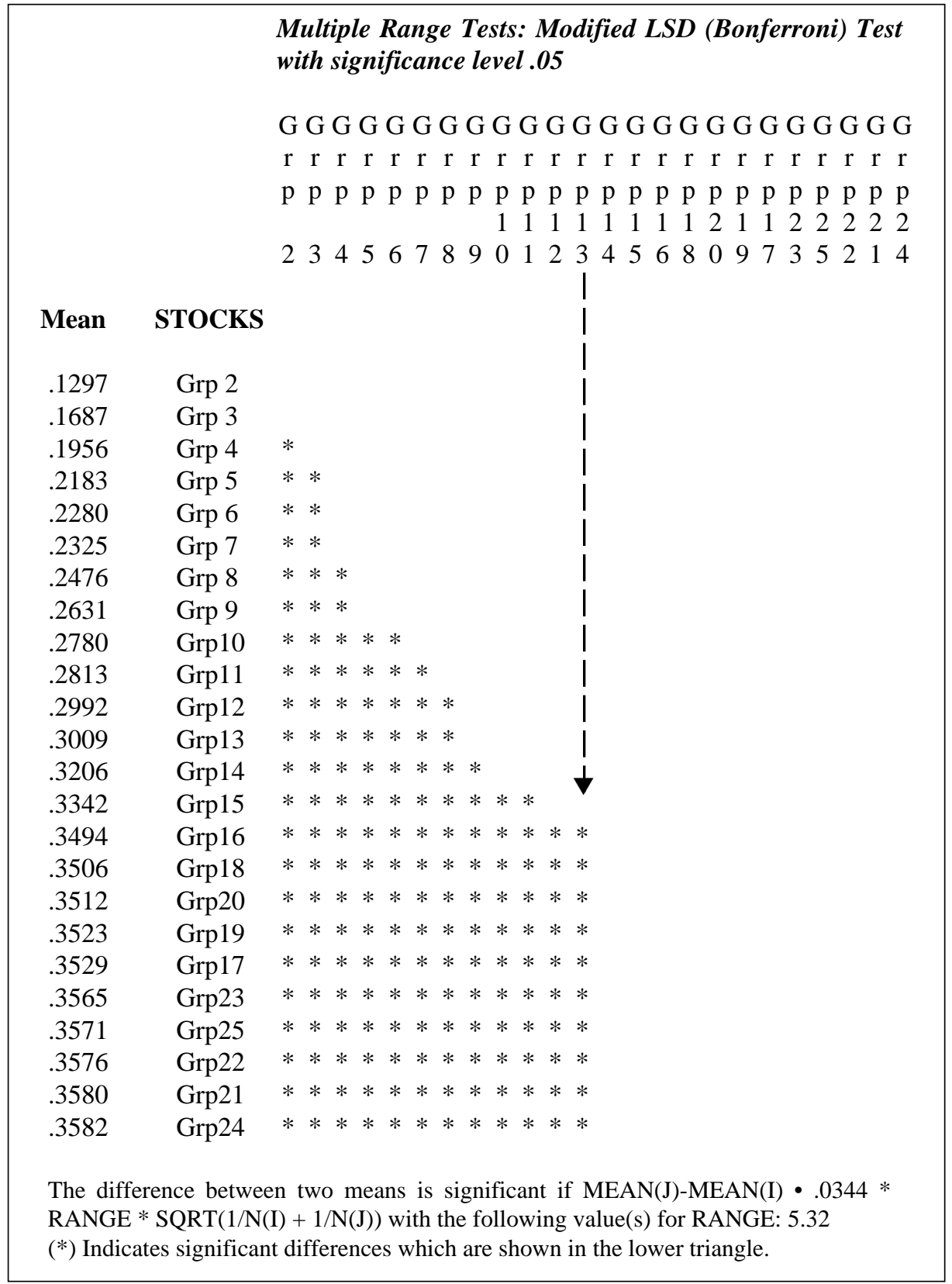


Table 4. Summary of ANOVA for 5 Groups of Portfolio Combination of Philippine Stocks.

\begin{tabular}{|c|c|c|c|c|c|}
\hline \multicolumn{6}{|c|}{$\begin{array}{l}\text { Analysis of Variance } \\
\text { (2 Stocks - } 5 \text { Stocks) }\end{array}$} \\
\hline Source & D.F. & $\begin{array}{l}\text { Sum of } \\
\text { Squares }\end{array}$ & $\begin{array}{c}\text { Mean } \\
\text { Squares }\end{array}$ & $\begin{array}{c}F \\
\text { Ratio }\end{array}$ & $\begin{array}{c}F \\
\text { Prob. }\end{array}$ \\
\hline $\begin{array}{l}\text { Between Groups } \\
\text { Within Groups } \\
\text { Total }\end{array}$ & $\begin{array}{r}3 \\
116 \\
119\end{array}$ & $\begin{array}{l}.1306 \\
.2449 \\
.3755\end{array}$ & $\begin{array}{l}.0435 \\
.0021\end{array}$ & 20.6204 & $.0000 *$ \\
\hline \multicolumn{6}{|c|}{ (6 Stocks - 10 Stocks) } \\
\hline Source & D.F. & $\begin{array}{c}\text { Sum of } \\
\text { Squares }\end{array}$ & $\begin{array}{c}\text { Mean } \\
\text { Squares }\end{array}$ & $\begin{array}{c}F \\
\text { Ratio }\end{array}$ & $\begin{array}{c}F \\
\text { Prob. }\end{array}$ \\
\hline $\begin{array}{l}\text { Between Groups } \\
\text { Within Groups } \\
\text { Total }\end{array}$ & $\begin{array}{r}4 \\
145 \\
149\end{array}$ & $\begin{array}{l}.0525 \\
.2812 \\
.3337\end{array}$ & $\begin{array}{l}.0131 \\
.0019\end{array}$ & 6.7634 & $.0001 *$ \\
\hline \multicolumn{6}{|c|}{ (11 Stocks - 15 Stocks) } \\
\hline Source & D.F. & $\begin{array}{l}\text { Sum of } \\
\text { Squares }\end{array}$ & $\begin{array}{c}\text { Mean } \\
\text { Squares }\end{array}$ & $\begin{array}{c}F \\
\text { Ratio }\end{array}$ & $\begin{array}{c}F \\
\text { Prob. }\end{array}$ \\
\hline $\begin{array}{l}\text { Between Groups } \\
\text { Within Groups } \\
\text { Total }\end{array}$ & $\begin{array}{r}4 \\
145 \\
149\end{array}$ & $\begin{array}{l}.0504 \\
.3780 \\
.4284\end{array}$ & $\begin{array}{l}.0126 \\
.0026\end{array}$ & 4.8379 & $.0011 *$ \\
\hline \multicolumn{6}{|c|}{ (16 Stocks - 20 Stocks) } \\
\hline Source & D.F. & $\begin{array}{c}\text { Sum of } \\
\text { Squares }\end{array}$ & $\begin{array}{c}\text { Mean } \\
\text { Squares }\end{array}$ & $\begin{array}{c}F \\
\text { Ratio }\end{array}$ & $\begin{array}{c}F \\
\text { Prob. }\end{array}$ \\
\hline $\begin{array}{l}\text { Between Groups } \\
\text { Within Groups } \\
\text { Total }\end{array}$ & $\begin{array}{r}4 \\
145 \\
149\end{array}$ & $\begin{array}{l}.0002 \\
.3877 \\
.3879\end{array}$ & $\begin{array}{l}.0001 \\
.0027\end{array}$ & .0213 & .9991 \\
\hline \multicolumn{6}{|c|}{ (21 Stocks - 25 Stocks) } \\
\hline Source & D.F. & $\begin{array}{c}\text { Sum of } \\
\text { Squares }\end{array}$ & $\begin{array}{c}\text { Mean } \\
\text { Squares }\end{array}$ & $\begin{array}{c}F \\
\text { Ratio }\end{array}$ & $\begin{array}{c}F \\
\text { Prob. }\end{array}$ \\
\hline $\begin{array}{l}\text { Between Groups } \\
\text { Within Groups } \\
\text { Total }\end{array}$ & $\begin{array}{r}4 \\
145 \\
149\end{array}$ & $\begin{array}{l}.0001 \\
.3538 \\
.3538\end{array}$ & $\begin{array}{l}.0000 \\
.0024\end{array}$ & .0057 & .9999 \\
\hline
\end{tabular}

(*) Multiple Range Tests: Modified LSD (Bonferroni) test with significance level.05 
Tandelilin—GainsfromInternationalDiversificationandDomesticPortfolioin...

Figure 5. Results of ANOVA for Optimum Number of Stocks in the Portfolio for Indonesian Stocks

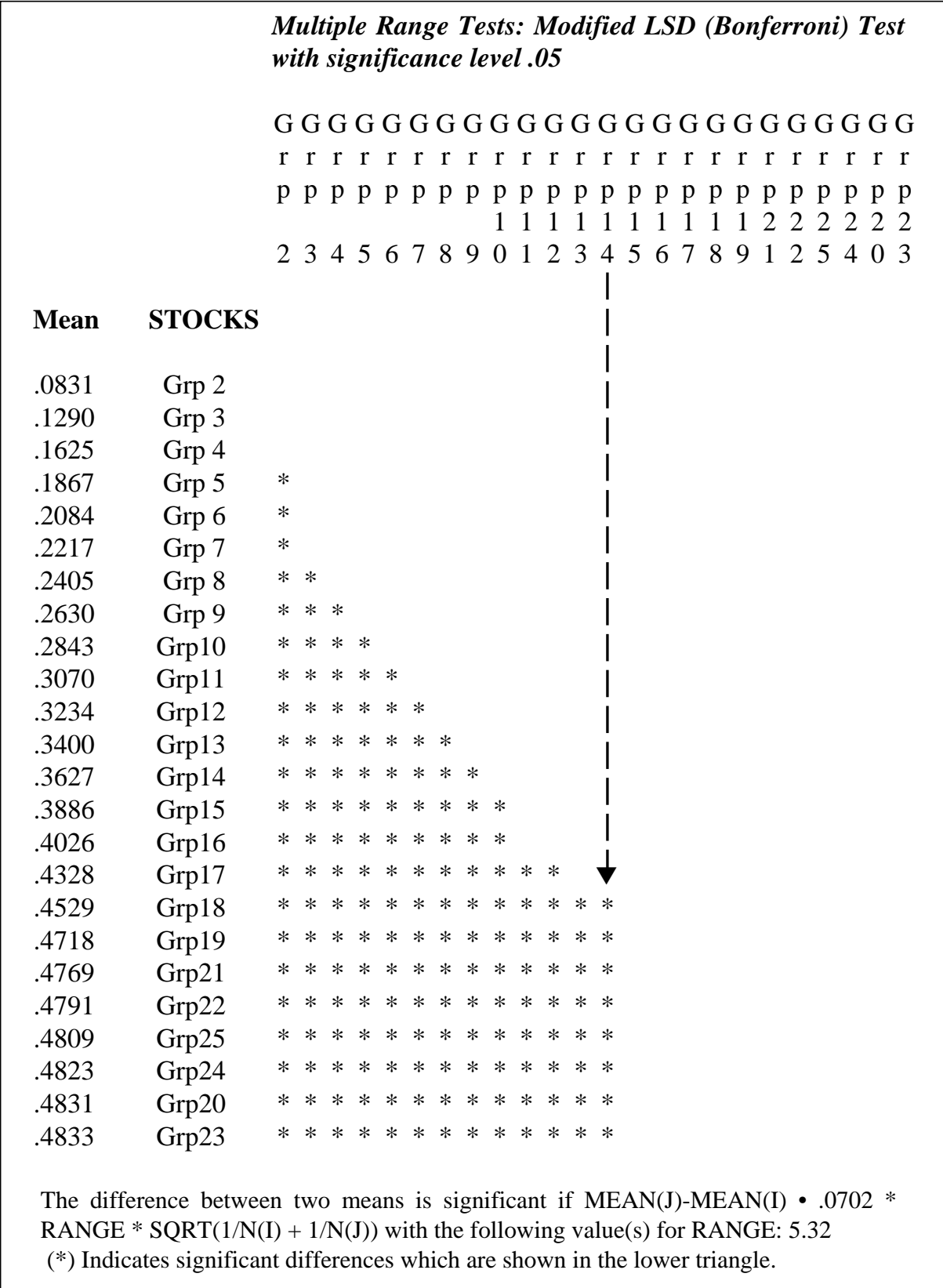


Table 6. Summary of ANOVA for 5 Groups of Portfolio Combination of Indonesian Stocks.

\begin{tabular}{|c|c|c|c|c|c|}
\hline \multicolumn{6}{|c|}{$\begin{array}{l}\text { Analysis of Variance } \\
\text { (2 Stocks - } 5 \text { Stocks) }\end{array}$} \\
\hline Source & D.F. & $\begin{array}{l}\text { Sum of } \\
\text { Squares }\end{array}$ & $\begin{array}{c}\text { Mean } \\
\text { Squares }\end{array}$ & $\begin{array}{c}F \\
\text { Ratio }\end{array}$ & $\begin{array}{c}F \\
\text { Prob. }\end{array}$ \\
\hline $\begin{array}{l}\text { Between Groups } \\
\text { Within Groups } \\
\text { Total }\end{array}$ & $\begin{array}{r}3 \\
116 \\
119\end{array}$ & $\begin{array}{l}.1811 \\
.6653 \\
.8465\end{array}$ & $\begin{array}{l}.0604 \\
.0057\end{array}$ & 10.5266 & $.0000 *$ \\
\hline \multicolumn{6}{|c|}{ (6 Stocks - 10 Stocks) } \\
\hline Source & D.F. & $\begin{array}{l}\text { Sum of } \\
\text { Squares }\end{array}$ & $\begin{array}{c}\text { Mean } \\
\text { Squares }\end{array}$ & $\begin{array}{c}F \\
\text { Ratio }\end{array}$ & $\begin{array}{c}F \\
\text { Prob. }\end{array}$ \\
\hline $\begin{array}{l}\text { Between Groups } \\
\text { Within Groups } \\
\text { Total }\end{array}$ & $\begin{array}{r}4 \\
145 \\
149\end{array}$ & $\begin{array}{r}.1127 \\
1.4680 \\
1.5807\end{array}$ & $\begin{array}{l}.0282 \\
.0101\end{array}$ & 2.7829 & $.0289 *$ \\
\hline \multicolumn{6}{|c|}{ (11 Stocks - 15 Stocks) } \\
\hline Source & D.F. & $\begin{array}{l}\text { Sum of } \\
\text { Squares }\end{array}$ & $\begin{array}{c}\text { Mean } \\
\text { Squares }\end{array}$ & $\begin{array}{c}F \\
\text { Ratio }\end{array}$ & $\begin{array}{c}F \\
\text { Prob. }\end{array}$ \\
\hline $\begin{array}{l}\text { Between Groups } \\
\text { Within Groups } \\
\text { Total }\end{array}$ & $\begin{array}{r}4 \\
145 \\
149\end{array}$ & $\begin{array}{r}.1243 \\
1.3815 \\
1.5058\end{array}$ & $\begin{array}{l}.0311 \\
.0095\end{array}$ & 3.2609 & $.0135 *$ \\
\hline \multicolumn{6}{|c|}{ (16 Stocks - 20 Stocks) } \\
\hline Source & D.F. & $\begin{array}{c}\text { Sum of } \\
\text { Squares }\end{array}$ & $\begin{array}{c}\text { Mean } \\
\text { Squares }\end{array}$ & $\begin{array}{c}F \\
\text { Ratio }\end{array}$ & $\begin{array}{c}F \\
\text { Prob. }\end{array}$ \\
\hline $\begin{array}{l}\text { Between Groups } \\
\text { Within Groups } \\
\text { Total }\end{array}$ & $\begin{array}{r}4 \\
145 \\
149\end{array}$ & $\begin{array}{r}.1235 \\
1.4287 \\
1.5521\end{array}$ & $\begin{array}{l}.0309 \\
.0099\end{array}$ & 3.1326 & $.0166 *$ \\
\hline \multicolumn{6}{|c|}{ (21 Stocks - 25 Stocks) } \\
\hline Source & D.F. & $\begin{array}{c}\text { Sum of } \\
\text { Squares }\end{array}$ & $\begin{array}{c}\text { Mean } \\
\text { Squares }\end{array}$ & $\begin{array}{c}F \\
\text { Ratio }\end{array}$ & $\begin{array}{c}F \\
\text { Prob. }\end{array}$ \\
\hline $\begin{array}{l}\text { Between Groups } \\
\text { Within Groups } \\
\text { Total }\end{array}$ & $\begin{array}{r}4 \\
145 \\
149\end{array}$ & $\begin{array}{r}.0008 \\
1.9256 \\
1.9264\end{array}$ & $\begin{array}{l}.0002 \\
.0133\end{array}$ & .0148 & .9996 \\
\hline (*) Multiple Rang & : Moc & LSD (Bon & oni) test v & significa & level.05 \\
\hline
\end{tabular}


In contrast with the Philippines' 14 stocks, the test reveals that no significant difference in SHP is obtained beyond 15 for Indonesia. This simply indicates that to form the optimal portfolio, an investor in Indonesia can invest in 15 stocks. This is reflected in Figure 5.

Further analysis (Table 6), however, indicate significant difference between holding 16 and 20 stocks. This is because of the high Sharpe Ratios (SHP) obtained from group 20, which may be peculiar to the particular sample obtained. Practical considerations, however, would indicate that 15 stocks be maintained in the Indonesia portfolio.

The difference may be attributed to the higher intercorrelation among the Philippine stocks. This implies that systematic risk may be higher in the Philippines than in Indonesia. According to Solnik (1995), as diversification increases, the risk of portfolio decreases but not proportionately. He added that very quickly the marginal reduction in variability of adding an extra security in the portfolio becomes smaller. In this study, the marginal increase of Sharpe ratio was used.

Moreover, Peavy and Rauscher (1994) stated that domestic diversification benefits accrue only for portfolios containing combination of stocks with varying levels of correlation. He added that a portfolio consisting of 20 stocks in different industries provide substantial diversification benefits as a result of the low cross-correlation coefficients (inter-correlation) among the individual securities. On the other hand, a portfolio comprised of 20 large oil companies achieves virtually no diversification benefits because the component securities are highly correlated. This contention may apply in the
Philippine setting as there is a lower optimal number of stocks to form an investment portfolio as compared to Indonesia. Franco Modigliani and Gerald Prague (as cited by Peavy and Rauscsher 1994) explained how most of the possible diversification benefits occur in a portfolio containing as few as 10 stocks in different industries. A 20-stock diverse portfolio derives virtually all possible diversification benefits within an asset class.

In terms of correlation, the Philippines' stocks have more significant intercorrelation as compared to the Indonesian stocks. As stated earlier, this explains the lesser number of stocks that form the portfolio of domestic investment from the Philippine perspective as compared to the Indonesian situation.

The findings of the current study provide some support to the contention of Sharpe (1995) on the significance of diversification in constructing a portfolio. He stated that "the more securities in a portfolio, the greater the likelihood that sufficient good fortune will appear to balance off the bad fortune." He added that the number of securities in a portfolio provides a fairly crude measure of diversification and that more non-market risks should be considered. Greater correlation is observed among the Philippine stocks which implies there is more systematic risk. The result is less effective diversification in terms of the number of securities for the Philippines (14) as compared to Indonesia (15). From this, it can be seen that Sharpe's viewpoint is supported by the Indonesian case, that is, the higher the non-market or unsystematic risk, the more effective the diversification on the basis of the number of securities in a portfolio. 


\section{Conclusion}

The study is generally focused on the benefits of portfolio diversification. Previous studies have shown that international diversification is now well accepted as a beneficial portfolio management alternative. The Asian Pacific stock markets have been cited as alternative financial interests for international diversification strategies because of their significant developments.

The study was organized into two major concerns. First, the study aimed at finding the gains from international diversification in emerging stock markets (Thailand, Malaysia, Taiwan, South Korea, Pakistan, and India) from the Philippine and the Indonesian perspectives and to determine which perspective yields the greater gains. Second, the study determined how many securities must be included to obtain an optimal investment portfolio from the Philippine and Indonesian perspectives.

The monthly International Finance Corporation (IFC) Price Indices, covering the years 1990 to 1995 , were used for all the emerging stock market samples. To compare the Philippine Stock Exchange (PSE) and the Indonesian Stock Exchange (JSX), 30 listed companies from PSE and 30 listed companies from JSX respectively were matched and randomly selected, for a total number of 60 non-financial firms. Monthly stock returns used for all the samples covered the years 19911995.

The findings were: First, there are gains from international diversification both from the Philippine and Indonesian perspectives in two to eight emerging stock markets. Generally, the gains are greater from the Indonesian perspective than the Philippine perspective in all country combinations. However, in terms of Mean
SHP (International Portfolio), the Philippines is higher than Indonesia in almost all possible country combinations (except 6 countries). Indonesia is higher in terms of percentage gains of Mean SHP in all country combinations. In terms of optimum SHPs, results are mixed. From the Indonesian perspective, it is higher for 2, 3, 4, 5 and 6-country combinations. On the other hand, optimum SHP is higher in 7-country combinations from the Philippine perspective. The Indonesian perspective yielded higher percentage gains of optimum SHP in all country combinations. Second, the tests show that fourteen (14) stocks comprise the optimum investment portfolio for the Philippines while fifteen (15) comprise that of Indonesia.

A superior investment strategy is one that can identify and reduce risks that bear on compensation. The reduction can be accomplished simply and effectively by means of diversification. Diversification is the most important concept in portfolio risk management. Improved diversification can produce higher returns at lower risk. The evidence presented in the study has important implications for the significance of portfolio diversification. Results of the study provide evidence that there are substantial benefits that can be gained through portfolio diversification in emerging stock markets from the Philippine and Indonesian perspectives. The results could be viewed largely as being indicative rather than conclusive because other variables such as currency and political risks were not integrated in the data analysis. As a whole, nonetheless, the benefits from international diversification are so large that foreign investors will be encouraged to place their money in these emerging markets. Eventually, this will rapidly resuscitate and further develop financial markets 
Tandelilin—Gainsfrom InternationalDiversificationandDomesticPortfolioin...

in the emerging stock markets in Asia, specifically in the Philippines and Indonesia.

The study reveals that there is a certain maximum limit for optimal domestic diversification. Moreover, the number of stocks to form an optimum investment portfolio differs for the Philippine and Indonesian perspectives.

\section{References}

Bailey, W., and Rene M. S. 1990. Benefits of international diversification: The case of Pacific Basin Stock Markets. The Journal of Portfolio Management (Summer): 5761.

Bart, J. 1992. International diversification: Part 1 - risk reduction \& return enhancement. Canadian Shareowner 5: 10-11, 19.

Brainard, W. C., and J. Tobin. 1992. On the internationalization of portfolio. Oxford Economic Papers 44 (October): 533-565.

Cooley, P. L., 1996. Advances in Financial Management. The Dryden Press: 103 - 109.

Cosset, J.C., and J. M. Suret . 1995. Political risk and the benefits of international portfolio diversification. Journal of International Business Studies (Second Quarter) 26: 301318.

Divecha, A. B., J. Drach, and D. Stefek. 1992. Emerging markets: A quantitative perspective. The Journal of Portfolio Management (Fall): 41-50.

Elton, E. J., and M. J. Gruber. 1995. Modern Portfolio Theory and Investment Analysis, $4^{\text {th }}$ Edition, John Wiley \& Sons.

Errunza, V. R. 1994. Emerging capital markets: Some new concepts. The Journal of Portfolio Management (Spring): 82-87.

Errunza, V. R., and P. Padmanabhan. 1988. Further evidence on the benefits of portfolio investment in emerging markets. Financial Analysts Journal (July-August): 76-78.

Eun, C. S., and B. G. Resnick. 1994. International diversification of investment portfolios: U.S. and Japanese perspective. Management Science (40) 1. January: 140-161.

Filatov, V. S., and P. Rappoport. 1992. Is complete hedging optimal for international bond portfolios?. Financial Analysts Journal (July-August): 37-47.

Francis, J. C. 1991. Investment: Analysis and Management. $5^{\text {th }}$ Ed, McGrow Hill Inc.: 204-251.

French, K. R., and J. M. Poterba. 1991. Investor diversification and international equity markets. Behavioral Finance (81) 2 (May): 222-226.

Haavisto, T., and B. Hansson. 1992. Risk reduction by diversification in the Nordic Stock Markets. Scandinavian Journal of Economics (94): 581-588. 
Iben, T., and R. Litterman. 1994. Have the benefits of international diversification diminished.? The Journal of Fixed Income (September): 27-34.

Lamberte, M. B. 1994. Managing surges in capital inflows: the Philippine Case. Paper Presented in $19^{\text {th }}$ Annual Conference of the Federation of Asean Economic Association and $32^{\text {nd }}$ Annual Conference of the Philippine Economic Society, December 89, 1994 (unpublished).

Levy, H., and Z. Lerman. 1988. The benefits of international diversification in bonds. Financial Analysts Journal (September-October): 56-64.

Levy, H., and M. Sarnat. 1970. International diversification of investment portfolios. American Economic Review (LX) 4 (September): 668-675.

Madura, J., and L. Soenen. 1992. Benefits from international diversification: across time and country perspectives. Managerial Finance (19): 1-14.

Michaud, R. O., G. L. Bergstrom, R. D. Frashure, and B. K. Wolahan. 1996. Twenty year of international equity investing. The Journal of Portfolio Management (Fall): 9-22.

Odier, P., and B. Solnik. 1993. Lessons for international asset allocation. Financial Analysts Journal (March-April): 63-77.

Peavy, J. W. III, and Mary Jo Vaughn-Rauscher,. 1994. Risk management through diversification. TRUSTS \& ESTATES (September): 42-46.

Pudjiastuti, E., and S. Husnan. 1994. Divesifikasi internasional: pengamatan terhadap beberapa bursa di Asia Pasifik. Kelola (5): 107-118.

Roll, R. 1995. An empirical survey of Indonesian equity 1985-1992. Pacific-Basin Finance Journal (3): 159-192.

Sharpe, W. F. 1995. Risk, market sensitivity, and diversification. Financial Analysts Journal (January-February): 84-88.

Solnik, B. 1995. Why not diversify internationally rather than domestically.? Financial Analysts Journal (January-February): 89-94.

Speidell, L. S., and R. Sappenfield. 1992. Global diversification in a shrinking world. The Journal of Portfolio Management (Fall): 57-67.

Ziobrowski, B. J., and A. J. Ziobrowski. 1995. Exchange rate risk and internationally diversified portfolio. Journal of International Money \& Finance (14): 65-81. 
Tandelilin—GainsfromInternationalDiversificationandDomesticPortfolioin...

Dr. Eduardus Tandelilin is Associate Professor of Finance and Executive Director of Quality for Undergraduate Education (QUE) Project at Faculty of Economics, Gadjah Mada University. 